\title{
Phospholipases C and D and Their Role in Biotic and Abiotic Stresses
}

\author{
Víctor M. González-Mendoza ${ }^{1,+}{ }^{(} \mathbb{D}$, M. E. Sánchez-Sandoval ${ }^{2,+}{ }^{(\mathbb{D}}$, Lizbeth A. Castro-Concha ${ }^{3}$ \\ and S. M. Teresa Hernández-Sotomayor ${ }^{3, *}$
}

1 CONACyT- Centro de Investigación en Alimentación y Desarrollo, A.C. Unidad Regional Hidalgo, San Agustín Tlaxiaca, Hidalgo 42163, Mexico; victor.gonzalez@ciad.mx

2 Department of Medical Biochemistry and Cell Biology, University of Gothenburg, 41390 Gothenburg, Sweden; eugensanch@gmail.com

3 Unidad de Bioquímica y Biología Molecular de Plantas, Centro de Investigación Científica de Yucatán, Mérida, Yucatán 97205, Mexico; liarcaco@cicy.mx

* Correspondence: ths@cicy.mx; Tel.: +52-999-942-83-30

+ These two authors contributed equally to this work.

Citation: González-Mendoza, V.M.; Sánchez-Sandoval, M.E.; CastroConcha, L.A.; Hernández-Sotomayor, S.M.T. Phospholipases C and D and Their Role in Biotic and Abiotic Stresses. Plants 2021, 10, 921. https:// doi.org/10.3390/plants10050921

Academic Editor: Eric Ruelland

Received: 31 March 2021

Accepted: 29 April 2021

Published: 4 May 2021

Publisher's Note: MDPI stays neutral with regard to jurisdictional claims in published maps and institutional affiliations.

Copyright: (c) 2021 by the authors. Licensee MDPI, Basel, Switzerland. This article is an open access article distributed under the terms and conditions of the Creative Commons Attribution (CC BY) license (https:// creativecommons.org/licenses/by/ $4.0 /)$.

\begin{abstract}
Plants, as sessile organisms, have adapted a fine sensing system to monitor environmental changes, therefore allowing the regulation of their responses. As the interaction between plants and environmental changes begins at the surface, these changes are detected by components in the plasma membrane, where a molecule receptor generates a lipid signaling cascade via enzymes, such as phospholipases (PLs). Phospholipids are the key structural components of plasma membranes and signaling cascades. They exist in a wide range of species and in different proportions, with conversion processes that involve hydrophilic enzymes, such as phospholipase-C (PLC), phospholipase-D (PLD), and phospholipase-A (PLA). Hence, it is suggested that PLC and PLD are highly conserved, compared to their homologous genes, and have formed clusters during their adaptive history. Additionally, they generate responses to different functions in accordance with their protein structure, which should be reflected in specific signal transduction responses to environmental stress conditions, including innate immune responses. This review summarizes the phospholipid systems associated with signaling pathways and the innate immune response.
\end{abstract}

Keywords: phospholipases; plant immune response; biotic stress

\section{Introduction}

All stimuli start at the surface and are detected by components of the plasma membrane, where a molecular receptor initiates lipid cascade signaling [1,2]. This can manifest as early or late signaling events that occur within minutes or hours after environmental responses and determine the outcome of stress triggers [3]. Phospholipid signaling responses have developed interrelated communication with immune systems to protect against the invasion of pathogenic microorganisms [4,5]. One system of phospholipid signal transduction recognizes and transduces responses through phospholipid-derived molecules as second messengers, which are common to many classes of microbes, including beneficial and pathogenic microbes [6,7]. This defense response is initiated by the recognition of microbes, pathogen-associated molecular patterns (PAMPs), or danger-associated molecular patterns (DAMPs), consisting of endogenous elicitor molecules [5,8,9]. The immunity conferred by PAMPs or DAMPs is termed pattern-triggered immunity (PTI), and the immunity conferred after it is activated by the plant resistance response is termed effector-triggered immunity (ETI), which can converge in a similar innate immune response [6].

Today, growing evidence suggests that within the plant-microorganism interactions, many actors, including receptors, such as leucine-rich repeats (NLRs), lipid-transfer proteins, and phospholipid signaling networks, play relevant roles in detecting, transmit- 
ting, and responding to a given environmental threat by inducing properly dosed responses [10,11]. The activation of transcriptional dynamics [12-14], which includes small RNAs, IncRNAs and miRNAs [15-19], alternative splicing [20], changes to the phosphoproteome [21], protein stability-mediated SUMOylation or ubiquitination [22], hormones as mediators [23,24], DNA-regulated methylation [25], and phosphoinositide pools as signals [26], appears to be a common phenomenon during susceptible interactions; all of these factors may control variations between susceptible and resistant phenotypes differently when faced with various plant pathogens [27]. Changes in lipids during signaling could involve the biogenesis of fatty acids, sterols, glycerolipids [28], sphingolipids, and phospholipids [29-31]. The changes in lipids are usually related to responses to environmental conditions, such as temperature, salinity, and water disposition, and events related to pathogen effects [32,33]. All of this evidence points to a relevant role for phospholipases (PLs) in signaling pathways leading to disease resistance or the innate immune response.

Previous research in our group highlights the important role of phospholipase C (PLC)/diacylglycerol kinase (DGK) in the signal transduction pathway employed in cell suspensions. These roles include reducing phosphatidic acid (PA) levels (by almost 30\%), PLC inhibition [34], and rapid activation of PLC transcription in mere minutes [35], all of which are responses to aluminum stress. Additionally, high levels of diacylglycerol pyrophosphate (DGPP) and PA were found in response to consortium infection involving PLC/DGK pathways [36]. This evidence establishes that PLDs produce another PA pool in response to different stresses. All of these findings point towards relevant crosstalk within PLC/PLD signaling pathways that lead to disease resistance or innate immune responses.

\section{Actions of Phospholipases in Plants}

\subsection{Phospholipase $C$}

PLC hydrolyses the phosphodiester bond on the glycerol side of phospholipids to produce diacylglycerol (DAG) and a phosphorylated head group [37]. PLCs have been classified based on their substrate or cellular function as whole enzymes with specific substrates, such as phosphatidylinositol $(4,5)$ bisphosphate $\left(\mathrm{PI}(4,5) \mathrm{P}_{2}\right)$, or phosphatidylinositol (4) phosphate $(\mathrm{PI}(4) \mathrm{P})$ [38]. DAG is subsequently phosphorylated by a diacylglycerol kinase (DGK) into phosphatidic acid (PA), and then, PA or diacylglycerol pyrophosphate (DGPP) is employed as a second messenger during signaling based on the surrounding responses [29].

\subsection{PLC Structure}

PLCs in most organisms have been classified into multiple subfamilies; mammalian PLCs consist of 13 members grouped into the isoforms PLC $\beta, \gamma, \delta, \varepsilon, \eta$, and $\zeta$, while plants have just one kind of PLC called PLC $\zeta$, which lacks the pleckstrin homology (PH) domain [39]. PLCs have been reported in many different species, including Arabidopsis. Using BLAST and PLC sequences from Arabidopsis as a query in plant databases, such as PlantGDB, SOL Genomics Network, EnemblPlants, Miyakogusa, and RAP-DB, different PLCs from plants have been identified [40-74]. Multiple PLCs have been registered in Arabidopsis (AthPLC1-9; Arabidopsis thaliana L. Heynh; [40]), grapevine (VviPLC1-5; Vitis vinifera L.; [41]), peach (PpePLC1-4; Prunus persica L. Stokes; [42]), papaya (CpaPLC1-4; Carica papaya L.; [43]), cucumber (CsaPLC1-4; Cucumis sativus L.; [44]), cassava (MesPLC14; Manihot esculenta Crantz; [45]), robusta coffee (CcaPLC1-4; Coffea canephora L.; [46]), black cottonwood (PotPLC1-4; Populus trichocarpa; [47]) and an external group, the moss Physcomitrella (PpPLC1-7; Physcomitrella patens; [48]). For some Solanaceae, 7 isoforms of PLC have been registered, including those in potato (StuPLC1-7; Solanum tuberosum L.; [49]), tomato (SolPLC1-7; Solanum lycopersicum L.; [50]), eggplant (SmePLC7; Solanum melongena L.; [51]), pepper (CanPLC1-7; Capsicum annum L. cv CM334; [52]), benthi (NbePLC1-7; Nicotiana benthamiana Domin; [53]), tobacco (NtaPLC1-7; Nicotiana tabacum L.; [54]) and petunia (PinPLC1-7; Petunia integrifolia Hook; [55]). For Gramineae, four isoforms of PLC have been registered in rice (OsaPLC1-4; Oryza sativa var. Japonica; [56]), stiff brome 
(BrdPLC1-4; Brachypodium distachyon (L.) P. Beauv; [57], great millet (SbiPLC1-4; Sorghum bicolor L. Moench; [58]), foxtail millet (SitPLC1-4; Setaria italica (L.) P. Beauv; [59]) and maize (ZmaPLC1-4; Zea mays L.; [60]). Finally, leguminous isoforms of PLC have been registered in soybean (GmaPLC1-3; Glycine max L. Merr; [61]) and wild legumes (LjaPLC1-4; Lotus japonicus L.; [62]).

PLCs from plants were subjected to phylogenetic analysis and organized into seven well-defined specific groups. PLC2 and PLC7 from many species formed a clade called type A (Figure 1). PLC1 and PLC3 formed another neighboring group called type B (Figure 1). PLC4 formed an exclusive group called type C, though PLC4 from Gramineae formed a separate group called type C'. PLC5 and PLC6 from Solanaceae formed a fourth clade called type D together with AthPLC6 (Figure 1). PLCs from monocots formed an exclusive group that included PLC1, PLC2 and PLC3 called type AB, and in the same manner, PLC3 from leguminous plants formed another exclusive group called type D' (Figure 1). Finally, PLCs from the moss Physcomitrella formed a separate external group, as predicted. These findings indicated that highly conserved PLCs from different plants might have similar functions in the evolution of plants. Hence, the structures of PLCs from Solanaceae were different from those of Gramineae or leguminous PLCs, and these differences might be correlated with functional differences.

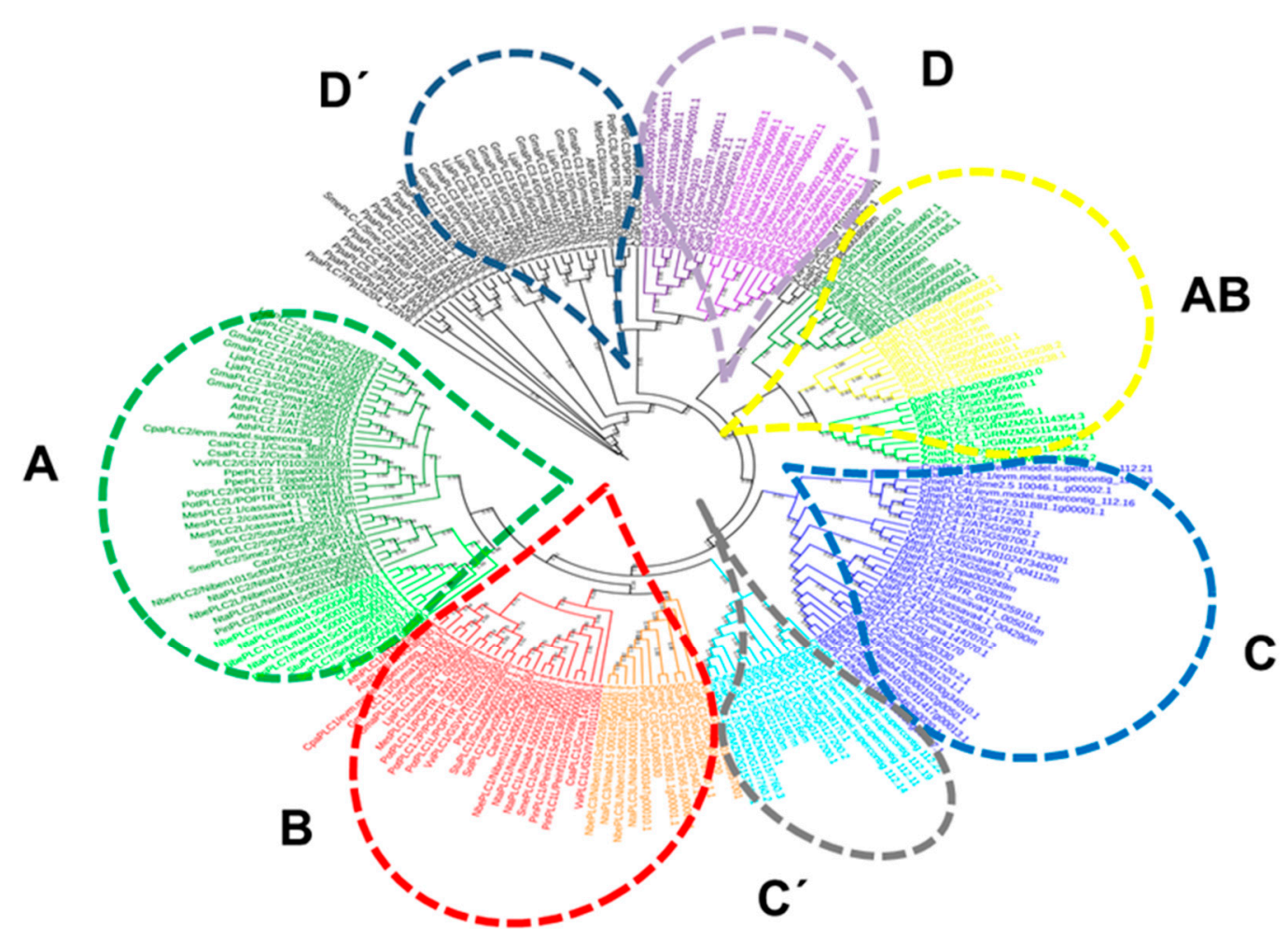

Figure 1. Phylogenetic tree of PLCs from plants. The phylogeny was reconstructed based on an alignment and was made by using the maximum parsimony method, with 1000 bootstrap replicates; the results were visualized using MEGA X and ITOL. Group A comprises PLC2 and PLC7; group B comprises PLC1 and PLC3; group AB comprises PLC1, PLC2, and PLC3 from Gramineae; group C comprises PLC4; group D comprises PLC6 and PLC5 from Solanaceae together with AthPLC6; an exclusive group $C^{\prime}$ comprises PLC4 from Gramineae; and group D' comprises PLC3 from legumes. Finally, the moss Physcomitrella forms an external group. The numbers at the nodes are the bootstrap values ( $>50 \%)$, and the branch lengths from the root are displayed.

PLCs from plants presented a simple general structure with catalytic $X$ and $Y$ domains, an EF domain, and a C2 lipid-binding domain [63]. PLCs depend on the $\mathrm{Ca}^{2+}$ concentration in vitro (in a micromolar or millimolar range) [64], and are assumed to be in vivo substrates of PtdIns(4,5) $\mathrm{P}_{2}$ or PtdIns(4)P [33]. The I-TASSER suite was employed in a hierarchical 
approach to protein structure prediction and structure-based function annotation, and full-length atomic models of multiple PLCs were reconstructed by iterative template-based fragment assembly simulations (with server https:/ / zhanglab.ccmb.med.umich.edu/ITASSER/, accessed on 16 March 2021 [65]). PLCs from Arabidopsis and others showed the characteristic catalytic $X$ and $Y$ domain organization that forms a TIM barrel-like structure essential for their phosphoesterase activity [33]. AthPLC1 showed structural features that included an open TIM barrel-like (OBL; Figure 2) or a non-fist-like structure, while AthPLC3 featured an OBL structure modified without a lid (OBLm; Figure 2) or a non-fist-like structure without a thumb. AthPLC2 showed a closed TIM barrel-like (CBL; Figure 2) or a closed-fist structure, while AthPLC4 presented as a CBL structure with a handle $(\mathrm{CB}+\mathrm{H}$; Figure 2$)$ or a closed-fist structure with a raised pinky, and AthPLC6 had a TIM barrel-like structure with or without a rod (CB-R; Figure 2) or a closed-fist structure without fingers. AthPLC7 showed a similar open TIM barrel-like structure as AthPLC1 and AthPLC5, while AthPLC8 and AthPLC9 were shown to have modified or incomplete TIM barrel-like structures with a handle (CB+Hm: Figure 2). In accordance with the phylogenetic arrangement, AthPLC1 and AthPLC3 shared an open TIM barrel-like structure to form clade type A (Figure 1). While AthPLC2 showed a closed TIM barrel-like structure, AthPLC7 did not; however, they shared a defined TIM barrel-like structure with small differences when grouped into clade type B (Figure 1). With respect to other PLCs, these PLCs showed changes in their TIM barrel-like structures or incomplete TIM barrel-like structures via modifications to the beta-sheet motif that resembled a bent thumb in AthPLC5 or an incomplete TIM barrel-like structure in AthPLC8 and AthPLC9; they all formed group $\mathrm{C}$ together with AthPLC4 (Figure 1). An exceptional case was AthPLC6, which resembles a rodless barrel and lacks internal beta sheet motifs inside the catalytic $X$ and $Y$ domains. With respect to other PLCs, these structures resembled PLCs from Arabidopsis, with an exception being PLC6 from Solanaceae, which presented an extra domain that resembled an external cap-like domain [40,66-68], and another strap-like domain similar to some Gramineae, such as great millet and foxtail millet. These protein clusters suggested different adaptative strategies in Solanaceae with respect to other plants, similar to monocots. Therefore, we hypothesized that different functions in transduction signaling based on specific PLC structures should be tested in the future.

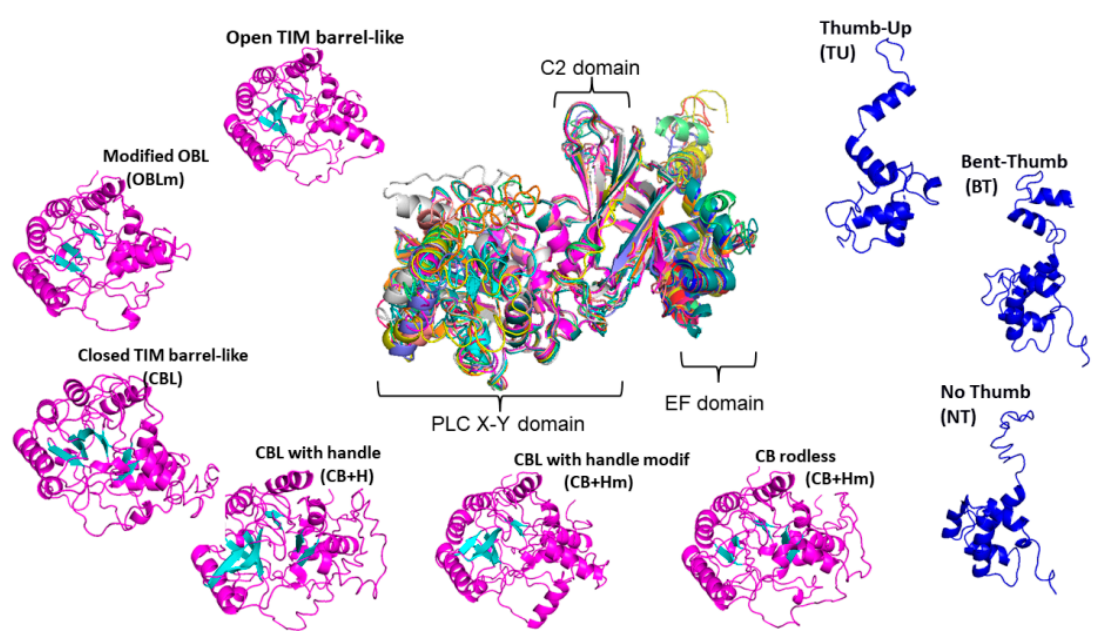

Figure 2. Postulated TIM barrel-like PLC structural types. Predicted PLC structures were classified as open TIM barrel-like (OBL); modified OBL (OBLm); closed TIM barrel-like (CBL or CBLm); CBL with handle $(\mathrm{CB}+\mathrm{H}$ or $\mathrm{CB}+\mathrm{Hm})$; and TIM barrel-like without an internal beta sheet motif (CB-R). In accordance with modifications in the EF-hand domains, three kinds of structures were predicted: Thumb-up domain (TU), bent-thumb (BT), or no thumb domain (NT).

With respect to other motifs, many proteins share a particular type of calcium-binding domain, known as the EF-hand. The EF-hand consists of an alpha-helical motif loop flanked 
on both sides by three other alpha-helical motifs, such as a spring domain. Some Glu or Asp residues are involved in ligand binding to $\mathrm{Ca}^{2+}$ and provoke a conformational change for activation or inactivation of the catalyzed enzymatic reactions for these enzymes [69]. The PLCs presented three types of EF-hands that resembled the thumb domain (Figure 2). While AthPLC1, 3, 4, and 7 showed thumb-up domains (TUs), AthPLC6 showed a bentthumb domain (BT), and AthPLC2, 5, 8, and 9 showed no thumb domains (NT). Finally, the C2 lipid-binding domain was present in some PLCs from plants.

\subsection{Nonspecific Phospholipase C}

Whereas, PLCs use phosphoinositide specificity, nonspecific phospholipase C (NPC) uses common phospholipids, such as phosphatidyl-choline (PC) and phosphatidyl-ethanolamine (PE), as substrates to produce DAG and a corresponding phosphate-containing polar head group [70]. In addition to their inherent signaling functions, NPCs also play a role in lipid metabolism [33]. Based on sequence similarity with bacterial PC-PLC, six NPC genes (NPC1-NPC6) were identified in the Arabidopsis genome. NPCs possess a phosphoesterase domain necessary for esterase activity and three unknown domains that are highly conserved with a bacterial (Mycobacterium tuberculosis) PC-PLC [71]. The NPC backbone consists of a $\beta$-sheet surrounded by seven $\alpha$-helixes and is in the non-membranespanning region. NPC participates in signaling, lipid metabolism, and development [72,73], and is involved in stress conditions, such as phosphate starvation [71], salt stress [72,74,75], aluminum toxicity [76-78], heat stress response [79], and infections with pathogens, such as Pseudomonas syringae [80].

\subsection{Phospholipase D}

PLD hydrolyzes phospholipids at the terminal phosphodiester bond, generating a free head group and PA. PLD mainly uses PE or PC, as well as others, as a substrate to produce PA, which alongside DGPP can be employed as a second messenger during signaling in plants [33]. PLDs participate in signaling, transport, and membrane degradation and are involved in stress conditions, such as drought stress (dehydration and salt stress), freezing, wounding, and pathogen interactions [81].

\subsection{PLD Structure}

PLDs have been organized into five subfamilies $(\alpha, \beta, \gamma, \delta, \varepsilon$ and $\zeta), 12$ of which have been described in Arabidopsis (Figure 3). PLD has two highly conserved domains called PLDc that are essential for its phosphoesterase activity [82]. While a characteristic C2 lipid-binding domain has previously been shown, C2-PLDs include PLD $\alpha$, PLD $\beta$, PLD $\gamma$, PLD $\delta$, and PLD $\varepsilon$ and utilize PC, PE, and phosphatidylglycerol (PG) as substrates, but with different preferences [33]. PLD $\zeta$ lacks the $C 2$ domains and includes a pleckstrin homology $(\mathrm{PH})$ domain near the N-terminus; it selectively uses PC as a substrate [83]. In plants, multiple PLDs have been found, such as in Arabidopsis (AthPLD $\alpha 1-3, \beta 1-2$, $\gamma 1-3, \delta, \varepsilon$ and $\zeta 1-2 ;$ [83]) (Figure 3), grapevine (VviPLD $\alpha 1-3(5), \beta(1), \gamma(1), \delta 1-3(3), \varepsilon(1)$ and $\zeta(1)$; [41]), peach (PpePLD $\alpha 1-3(3), \beta(1), \gamma(1) \delta 1-2(2), \varepsilon(1)$ and $\zeta 1-2(2)$; [42]), papaya (CpaPLD $\alpha 1,3(2), \beta(1), \gamma 1-1(2), \delta 1(2), \varepsilon(1)$ and $\zeta 1-2(2)$; [43]), cucumber (CsaPLD $\alpha 1-3(3)$, $\beta(1), \gamma(1), \delta 1-2(2), \varepsilon(1)$ and $\zeta 1-2(3)$; [44]), cassava (MesPLD $\alpha 1-3(3), \beta(1), \gamma(1), \delta 1-3(7)$, $\varepsilon(1)$ and $\zeta 1-2(3)$; [45]), robusta coffee (CcaPLCD $\alpha 1-3(4), \beta(1), \gamma(1), \delta 1-3(3), \varepsilon(1)$ and $\zeta 1-$ 2(2); [46]), black cottonwood (PotPLD $\alpha 1-3(7), \beta 1-2(2), \gamma(1), \delta 1-3(7), \varepsilon(1)$ and $\zeta 1-2(3) ;[47])$ and an external group, the moss Physcomitrella (PpPLD $\alpha 1-2(5), \beta 1-2(2), \gamma 1-2(2), \delta(1), \varepsilon(1)$ and $\zeta(2) ;[48])$. For some Solanaceae, different isoforms have been registered in potato (StuPLD $\alpha 1-3(6), \beta 1-2(2), \gamma(1), \delta 1-3(5), \varepsilon(1)$ and $\zeta 1-2(2)$, tomato (SolPLD $\alpha 1-3(6), \beta 1-2(2), \gamma(1)$, $\delta 1-3(5), \varepsilon(1)$ and $\zeta 1-2(2)$, eggplant (SmePLD $\alpha 1-3(5), \beta 1-2(2), \gamma(1), \delta 1-2(4), \varepsilon(1)$ and $\zeta 1-2(2)$, pepper (CanPLCD $\alpha 1-3(5), \beta 1-2(2), \gamma 1-2(2) \delta 1-3(4), \varepsilon(3)$ and $\zeta 1-2(3)$, benthi (NbePLD $\alpha 1-$ 3(6), $\beta 1-2(4), \gamma 1-2(2), \delta 1-3(8), \varepsilon(2)$ and $\zeta 1-2(3)$, tobacco (NtaPLD $\alpha 1-3(7), \beta 1-2(4), \gamma 1-2(2)$, $\delta 1-3(9), \varepsilon(1)$ and $\zeta 1-2(4)$ and petunia (PinPLD $\alpha 1-3(5), \beta 1-2(2), \gamma(1), \delta 1-3(5), \varepsilon(1)$ and $\zeta 1-$ 2(2). For Gramineae, some isoforms have been registered in rice (OsaPLD $\alpha 1-3(7), \beta(1)$, 
$\gamma(1), \delta 1-3(3), \varepsilon(1)$ and 11-2(3) [84-94], stiff brome (BrdPLD $\alpha 1-3(4), \beta 1(2), \delta 1-2(2), \varepsilon(1)$ and $\zeta 1-2)(3)$, great millet (SbiPLD $\alpha 1-3(6), \beta(1), \gamma(1), \delta 1-2(2), \varepsilon(1)$ and $\zeta 1-2(4)$, foxtail millet (SitPLD $\alpha 1-3(5), \beta 1(1), \gamma(1), \delta 1-2(3), \varepsilon(1)$ and $\zeta 1-2(3)$ and maize (ZmaPLD $\alpha 1-3(5), \beta(1)$, $\delta 1-2(3), \varepsilon(1)$ and $\zeta 1-2(3)$ [95-102]. Finally, leguminous isoforms have been registered in soybean (GmaPLD $\alpha 1-3(3), \beta 1-2(3), \gamma(1), \delta 1(3), \varepsilon(2)$ and $\zeta 1-2(3)$ [103-105], and wild legumes (LjaPLCD $\alpha 1-3(6), \beta 1-2(4), \gamma 1-2(2), \delta 1-3(7), \varepsilon(3)$ and $\zeta 1-2(4)$.

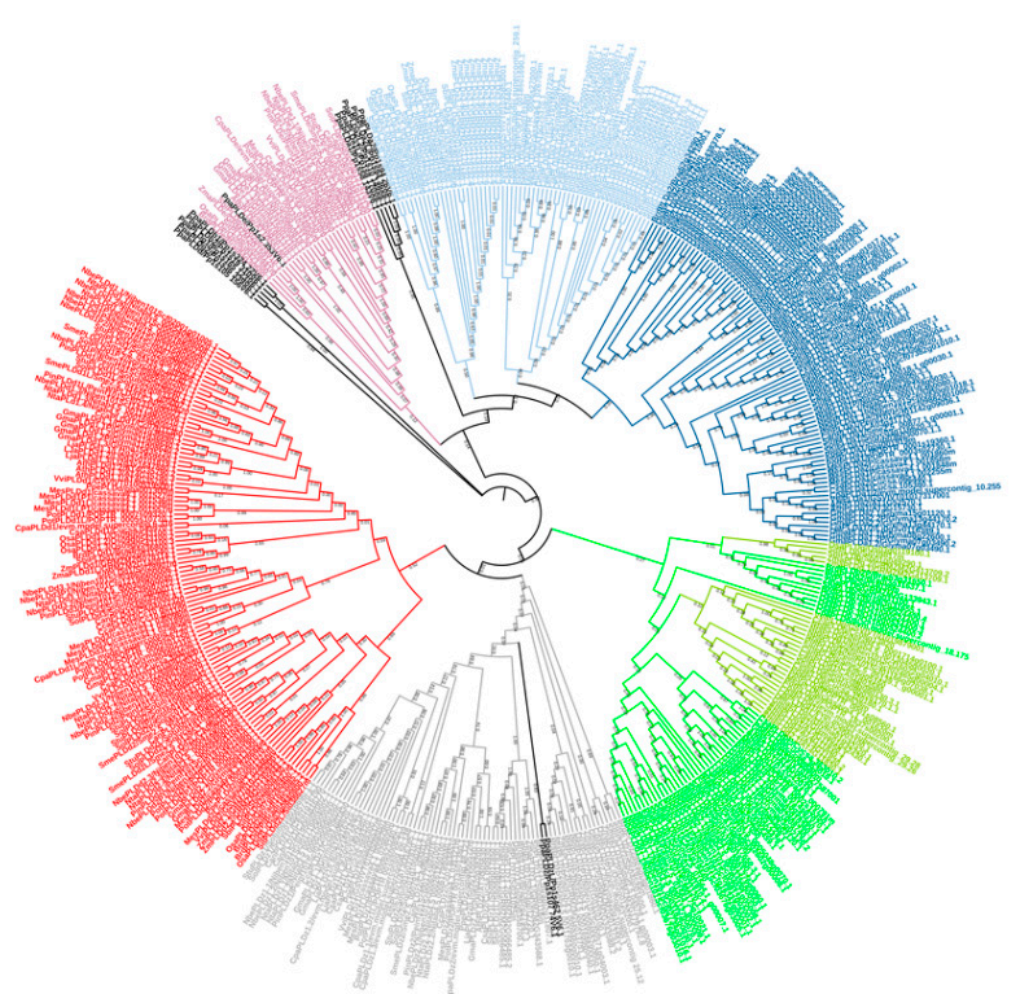

Figure 3. Phylogenetic tree of PLDs from plants. The phylogeny was reconstructed based on an alignment and was made using the maximum parsimony method, testing with 1000 bootstrap replicates and displayed using MEGA $X$ and ITOL tools. They were shown as follows, for PLD $\alpha$ in blue [1 and 2 (dark ones) and 3 (light one)], PLD $\beta$ in dark green, PLD $\gamma$ in light green, PLD $\delta$ in red, $\mathrm{PLD} \varepsilon$ in purple, and $\mathrm{PLD} \zeta$ in gray. Finally, in an external group, the moss Physcomitrella; the numbers at the nodes are the bootstrap values $(>50 \%)$, and the branch lengths from the root were displayed.

PLDs from plants contain two duplicated catalytic HKD (PLDc) motifs that interact with each other to form the active site, a C2 lipid-binding domain close to the N-terminus at approximately residue 130, which acts as a binding site for $\mathrm{Ca}^{2+}$ [83]. The Simple Modular Architecture Research Tool (SMART; http:/ / smart.embl.de, accessed on 16 March 2021) was employed as a web resource for the identification and annotation of protein domains and the analysis of protein domain architectures [106]. All PLDs have the PLDc motif or HKD, but some isoforms have lost motifs (Figure 4). AthPLD $\alpha, \beta, \gamma, \delta$ and $\varepsilon$ showed C2, but not PH domains, while PLD $\zeta$ showed PH, but not C2 domains [107-126]. In general, all PLDs from plants followed this trend, with the exception of extra PLDc2 and Phox homology (PX) domains in some PLD $\zeta$ s in Gramineae, such as stiff brome, great millet, foxtail millet, and maize, but not rice, and other types of different domains, such as RPTs, as internal repeats. When in Arabidopsis, all PLD structures were compiled using a swissmodel platform based on a crystal structure from AthPLD $\alpha 1$ called $6 \mathrm{KZ}$, as a template for the rest PLD $\alpha, \beta, \gamma, \delta$ and $\varepsilon$, and finally, a structure of a catalytic domain from Human PLD named 6u8z and 6ohr were used as a base for PLD $\zeta 1$ and 2, respectively (Figure 4). All $\operatorname{PLD} \alpha, \beta, \gamma, \delta$ and $\varepsilon$ showed a similar structure to AthPLD $\alpha 1$, but with slight modifications, 
such as being without an internal alpha helical and without C2 domain structure in PLD $\zeta 1$ and 2 , respectively.

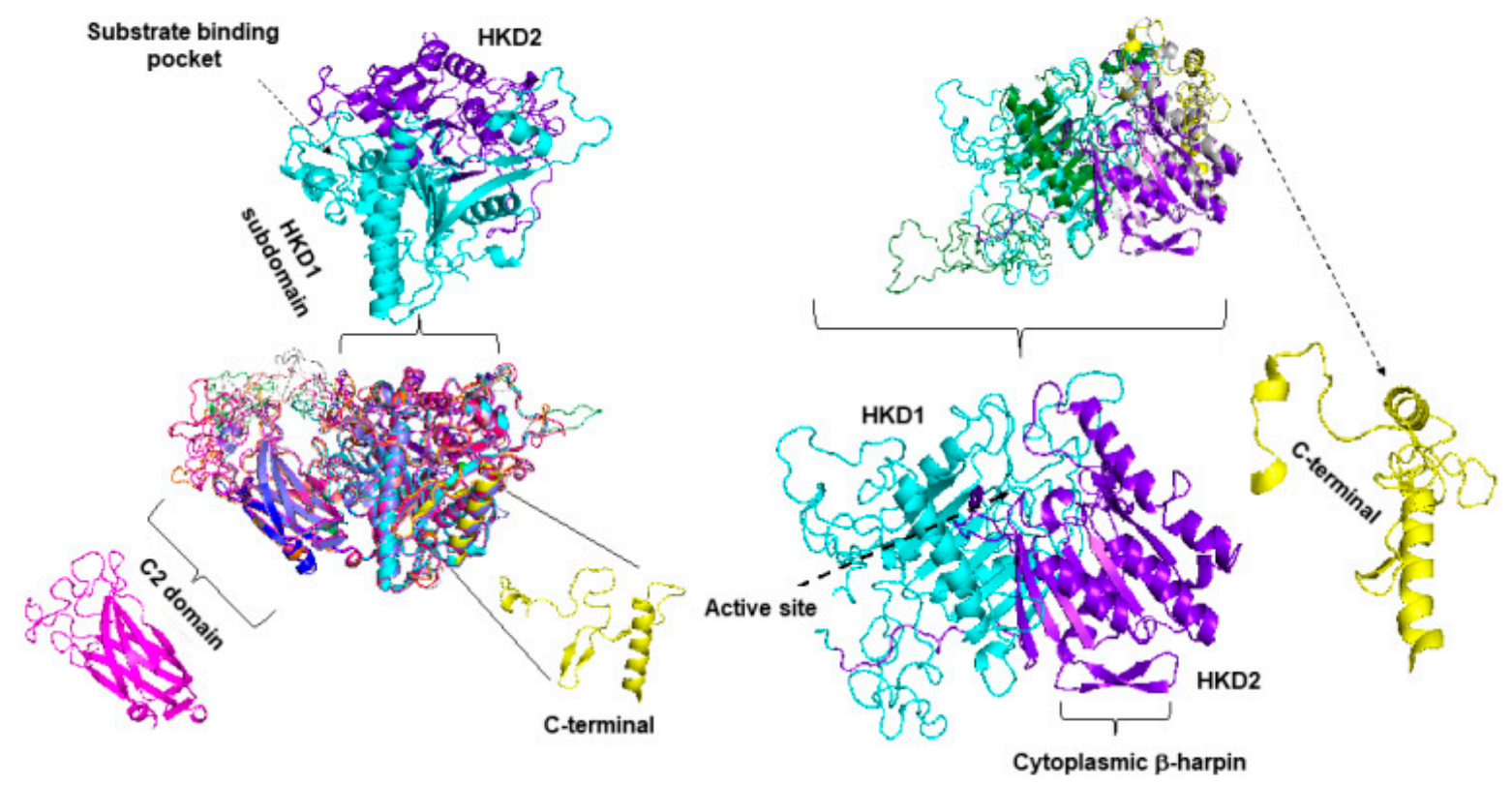

Alignment PLD $\alpha 1-3, \beta 1-2, \gamma 1-3, \delta, \varepsilon$

Alignment PLD81-2

Figure 4. Postulated PLD structure types. Predicted PLD structures were compiled in a swiss-model platform based on a crystal structure from Arabidopsis phospholipase D alpha called 6KZ9 as a template for PLD $\alpha, \beta, \gamma, \delta$ and $\varepsilon$ and structure of a catalytic domain from Human PLD named 6u8z and 6ohr for PLD $\zeta 1$ and 2, respectively.

\section{Phospholipid Signaling Responses Mediate the First Step during Immune Responses in Plants}

Phospholipases have long been associated with responses to stress. As the first barrier against environmental agents, PLs crosstalk with $\mathrm{PA}$ and $\mathrm{IP}_{3}$ because they are involved in signaling events within many organisms [2,127-129]. Elicitors, such as peptidoglycans (PGNs) and lipopolysaccharide (LPS), from bacterial cell envelopes, bacterial elongation factor thermo-unstable (EF-TU), flg22 (a 22-amino acid peptide derived from bacterial flagellin), chitin from fungal cell walls, and glucans and glycoproteins in oomycetes have been linked to responses to biotic stress [130]. These elicitors can trigger physiological and morphological changes and generate reactive oxygen species (ROS) [10].

\subsection{The Roles of PLCs in Immune Responses}

Today, more evidence suggests that the PI-PLC family is required for HR-mediated defense responses by the induction of ETI- or PAMP-triggered immunity. Elicitor-induced PA accumulation was reduced by inhibitors of PLC activity, such as neomycin and U73122, and ROS production in tobacco cells was elicited $[37,131]$. A rice PLC isoform, OsPI-PLC1, was used to evaluate an incompatible interaction between a resistant genotype of rice and Magnaporthe grisea; its expression was only induced in BTH-treated rice seedlings or Xanthomonas oryzae-treated cell suspension cultures, suggesting that OsPLC1 plays important roles in signaling pathways leading to disease resistance in rice [132,133].

However, PLC isoforms from tomato, SIPLC2 and SIPLC5, showed increased transcript levels upon inoculation with Cladosporium fulvum or when they were induced with fungal elicitors, such as xylanase or chitosan, suggesting general roles of SIPLC2 and SlPLC5 in the activation of plant defense responses with the involvement of nitric oxide (NO) in the regulation of these PLC genes and the subsequent defense response [27,134]. For SIPLC2, a role in the interaction with the necrotrophic fungus Botrytis cinerea was proposed, due 
to the increase in SIPLC2 transcript levels together with those of SIPLC3, SIPLC4, and SIPLC5 when specimens were inoculated with the necrotrophic fungus. PLC2 silencing via infection with tobacco rattle virus (TRV) also resulted in the reduced production of reactive oxygen species [135]. Previously, SIPLC2 was involved in the xylanase-induced expression of an SA-dependent PR-1a gene when SIPLC2-silenced plants were used, indicating that it plays a role in SA signaling $[27,135]$. All these data point to a nascent role of PLCs in biotic stress-related functions in which localized oxidative burst-dependent PA is required to infect the host.

Previous experiments demonstrated that SIPLC6 is important for resistance protein signaling following infections with C. fulvum, Verticillium dahlia, and Pseudomonas syringae, while SIPLC4 is specifically and individually involved in the induction of a hypersensitive response (HR) triggered upon the detection of Avr4-carrying Cladosporium fulvum by the Cf-4 resistance protein [136]. In addition, the heterologous expression of SIPLC4 results in accelerated Avr4/Cf-4-induced HR in N. benthamiana [3]. For NbPLC2 from Nicotiana, increased susceptibility was registered when NbPLC2-silenced plants were challenged with a virulent strain of Ralstonia solanacearum. Plants confronted with infections with $R$. solanacearum, hrp-deficient $R$. solanacearum, P. fluorescens, or flg22 showed elevated NbPLC2 transcript levels [137]. In contrast, silencing NbPLC2s negatively affected the expression of PTI reporter genes, such as NbPR-4 (a marker gene for jasmonic acid signaling), and decreased the levels of jasmonic acid and jasmonoyl-L-isoleucine after inoculation [137]. In addition, transcriptional dysregulation by several PTI inducers and effectors, oxidative burst, stomatal closure, and callose deposition were all reduced in the silenced plants. Silencing NbPLC2s negatively affected the expression of PTI reporter genes, which could mediate immune responses, leading to the suppression of bacterial infections [137].

\subsection{The Action of PLDs in Cases of Biotic Stress}

Current data indicate that PLDs produce the majority of pathogen-induced PA, and the individual contributions of different PLD isoforms to plant defense responses and their crosstalk with other signals are great challenges to resolve [138]. Some studies have reported decreased HR after recognition of elicitors via partial inhibition induced by $n$ butanol and several single-knockout PLD mutants. In particular, the PLD $\alpha$, PLD $\beta$, PLD $\gamma$ and PLD $\delta$ isoforms displayed a related HR phenotype in the presence of n-butanol [139]. PLD $\alpha 1$-derived PA together with NADPH oxidase and heterotrimeric G $\beta$ subunit (AGB1) proteins are required and function, in the same way, to fully resist different $P$. syringae pv. tomato DC3000 (avrRpm1) strains [140].

The establishment of the PLD $\beta 1$-deficient P. syringae pathosystem revealed lower levels of pathogen-induced PA production and increased levels of the lysophospholipids LPC, LPE, and LPG, which are involved in the pathogen- and wounding-induced responses [5]. PLD $\beta 1$-deficient plants exhibited increased resistance to PstDC3000, but increased susceptibility to Botrytis cinerea combined with an increase in PLA activity, suggesting crosstalk between the PLD and PLA pathways in plant-pathogen interactions [5]. Tomato LePLD $\beta 1$ was induced by fungal elicitors, and RNAi knockdown of LePLD $\beta 1$ resulted in increases in the defense response and ROS production in PLD $\beta$-suppressed tomato cells [81]. Knockdown of PLDB1 in rice increased resistance against Pyricularia grisea and Xanthomonas oryzae pv. oryzae cinerea, and the accumulation of reactive oxygen species in the absence of pathogen infection suggest that PLDß1 is a negative regulator of the immune response [141]. The pld $\gamma 1$ and pld $\gamma 3$ mutants had significantly elevated cell death responses following AvrRpm1 recognition [139].

Finally, PLD $\delta$ isoforms were more resistant against the penetration of nonadapted powdery mildew fungi (Blumeria graminis f. sp. Hordei, Bgh), while n-butanol-mediated inhibition of PA production by PLD action increased the penetration rate of Bgh spores on leaves [142]. The mode of action was discovered with PLD $\delta$ knockout plants, where they caused losses of ETI-induced and cell wall-based defense against Pst DC3000 (AvrRpm1) or a loss of MTI-induced cell wall-based defense against the nonhost powdery mildew Erysiphe 
pisi, suggesting the roles of PLD in plant-microbe interactions and defense responses [139]. Finally, a multitude of PLD isoforms in the HR triggered by elicitors are involved in triggering cell wall-based defenses against pathogen infection and suggest that different PLDs present in common physiological processes have different modes of action.

\subsection{The Action of PLCs in Viral Replication}

During the replication of red clover necrotic mosaic virus (RCNMV) in Nicotiana benthamiana, $\mathrm{NbPLD} \alpha$, and $\mathrm{NbPLD} \beta$ and their derived PA were required for viral RNA replication. Consistent with these data, exogenous application of PA enhanced viral RNA replication in plant cells and plant-derived cell-free extracts [143]. Finally, curated PlaD data were analyzed, and the global landscape of public pathogenesis-related genes from the model plant Arabidopsis and three major crops (maize, rice, and wheat) was explored. Here, only PLAs, not PLDs or PLCs, were induced by viral treatment [68].

\section{Phospholipid Signaling Response as a Means to Alleviate Other Stresses}

Phospholipid signaling can contribute to the regulation of other stresses, potentially playing an important role in responses to abiotic stress. For PI-PLC isoforms, all AtPLCs, with the exception of AtPLC8, showed increased or decreased transcriptional expression in some microarrays in response to various environmental stimuli, such as cold, drought, salinity, water deficit or dehydration, heat stress, or thermotolerance [40-74].

\subsection{Roles of PLC in Temperature Changes}

An example of the role of phospholipids, such as phosphatidylinositol in the binding of signaling-related proteins, was observed through phosphorylation assays after $15 \mathrm{~min}$ of cold exposure, suggesting that phospholipids are part of the very early response after temperature drop [144]. One of the molecules considered a signaling molecule regulated by cold is PA, a product of DAG and the hydrolysis of PI $(4,5) \mathrm{P}_{2}$ by enzymes, such as PLC2. With respect to temperature changes, AtPLC3 and AtPLC9 were shown to play roles in thermotolerance by increasing $\mathrm{IP}_{3}$ levels with changes to intracellular $\mathrm{Ca}^{2+}$ and presented an additive effect on regulating heat stress [145-147].

\subsection{Roles of PLC in Osmotic Stress}

Plants use different strategies to cope with osmotic stress, and lipid signaling has been implicated as one of the factors in various plant systems. PLC3 overexpression conferred tolerance to drought stress accompanied by decreased sensitivity to ABA-induced stomatal closure in Arabidopsis thaliana and other plants, such as maize and tobacco [148]. PLC4 in Arabidopsis thaliana has been described as a negative regulator of signaling, such as saltinduced $\mathrm{Ca}^{2+}$ signaling [149]; similarly, the action of PLC9 is implicated in changes in $\mathrm{IP}_{3}$ mediated regulation of heat tolerance and $\mathrm{Ca}^{2+}$ requirements [145]. In rice, OsPLC1 elicited $\mathrm{Ca}^{2+}$ signals regulating salt tolerance, as OsPLC1 was translocated from the cytosol to the plasma membrane, where it can hydrolyze PtdIns4P [150]. Overexpression of PI-PLC2 from Brassica napus into canola induced significant changes in the expression profiles of stress-related genes and enhanced drought tolerance [151]. Additionally, overexpression of ZmPI-PLC1 enhanced the grain yield of maize under drought conditions, while suppression of ZmPI-PLC1 had the opposite effect [152].

\subsection{Action of PLD in Osmotic and Drought Stresses}

In plants, osmotic stress-triggered stomatal closure requires PLD action and crosstalk with third-messenger gaseous signaling molecules, such as hydrogen sulfide $\left(\mathrm{H}_{2} \mathrm{~S}\right)$ in Arabidopsis thaliana. PLD $\alpha 1$ and $\mathrm{H} 2 \mathrm{~S}$ alleviate osmotic stress by suppressing ROS and maintaining membrane integrity [153]. When PLD $\delta$ was associated with a wider stomatal aperture under osmotic stress, a lower $\mathrm{H} 2 \mathrm{~S}$ content or expressed L-cysteine desulfhydrase was shown (LCD; [154]). In both cases, PLD action enhances the alleviation of osmotic stress by triggering stomatal closure, which could reduce transpiration, prevent water 
loss, and maintain cell turgor pressure under drought stress [153,154]. Li and colleagues reported lipid profiling results and revealed that PLD contributed approximately $20 \%$ of the phosphatidic acid produced in plants during freezing and that overexpression of PLDS increased the production of phosphatidic acid species [144]. Moreover, the knockdown of PLD $\alpha 1$ was related to a decrease in the level of PA during freezing-induced hydrolysis of phosphatidylcholine, whereas overexpression increased freezing tolerance [155]. PLD $\alpha 1$ deficiency rendered plants insensitive to ABA and induced stomatal closure [156]. Knockout of PLD $\alpha 3$ rendered Arabidopsis more sensitive to salt stress, while overexpression of PLD $\alpha 3$ enhanced salt tolerance. It has been proposed that PLD $\alpha 3$ positively mediates plant responses to hyperosmotic stresses in a negative manner in response to ABA [157]. Currently, there is another interesting interaction in plants that is mediated by PLs action and nitric oxide (NO). $\mathrm{NO}$ enhances tolerance to abiotic stress by increasing proton pump and/or antiport activities and reducing hydrogen peroxide $\left(\mathrm{H}_{2} \mathrm{O}_{2}\right)$ levels; a PLD inhibitor (1-butanol) diminishes these effects. This suggests an important role of PLD signal transduction in this process [158-160].

\section{Conclusions and Perspectives}

In this review, information on phospholipases was compiled for a wide range of plant species. Analyses of the phylogenetic relationships, protein structures, and domains of PLCs indicated that PI-PLCs were highly conserved compared with their homologous genes. Additionally, other PC-PLCs (NPCs) and PLDs were analyzed, which showed that PLs may have important functions in signal transduction during biotic and abiotic stresses. Taken together, these results provide useful information for further study of the roles and functions of PLs in plants under environmental stress conditions, including innate immune responses.

Author Contributions: Conceptualization, S.M.T.H.-S., V.M.G.-M., and M.E.S.-S.; Writing-Original preparation, S.M.T.H.-S., V.M.G.-M., and M.E.S.-S.; Writing-Review and Editing, S.M.T.H.-S., V.M.G.M., M.E.S.-S., and L.A.C.-C.; Image Design, V.M.G.-M., M.E.S.-S., and L.A.C.-C. All authors have read and agreed to the published version of the manuscript.

Funding: This research received no external funding.

Acknowledgments: This work was supported by Centro de Investigación Científica de Yucatán.

Conflicts of Interest: The authors declare no conflict of interest.

\section{References}

1. Rodas-Junco, B.A.; Nic-Can, G.I.; Muñoz-Sánchez, A.; Hernández-Sotomayor, S.M.T. Phospholipid Signaling Is a Component of the Salicylic Acid Response in Plant Cell Suspension Cultures. Int. J. Mol. Sci. 2020, 21, 5285. [CrossRef] [PubMed]

2. Singh, A.; Bhatnagar, N.; Pandey, A.; Pandey, G.K. Plant phospholipase $\mathrm{C}$ family: Regulation and functional role in lipid signaling. Cell Calcium 2015, 58, 139-146. [CrossRef] [PubMed]

3. Abd-El-Haliem, A.M.; Joosten, M.H. Plant phosphatidylinositol-specific phospholipase $\mathrm{C}$ at the center of plant innate immunity. J. Integr. Plant Biol. 2017, 59, 164-179. [CrossRef]

4. Crabill, E.; Joe, A.; Block, A.; van Rooyen, J.M.; Alfano, J.R. Plant Immunity Directly or Indirectly Restricts the Injection of Type III Effectors by the Pseudomonas syringae Type III Secretion System. Plant Physiol. 2010, 154, 233-244. [CrossRef] [PubMed]

5. Zhao, J.; Devaiah, S.P.; Wang, C.; Li, M.; Welti, R.; Wang, X. Arabidopsis phospholipase D $\beta 1$ modulates defense responses to bacterial and fungal pathogens. New Phytol. 2013, 199, 228-240. [CrossRef]

6. Jones, J.D.G.; Dangl, J.L. The plant immune system. Nature 2006, 444, 323-329. [CrossRef]

7. Munnik, T.; Testerink, C. Plant phospholipid signaling: "in a nutshell”. J. Lipid Res. 2009, 50, S260-S265. [CrossRef]

8. Tsuda, K.; Somssich, I.E. Transcriptional networks in plant immunity. New Phytol. 2015, 206, 932-947. [CrossRef]

9. Amari, K.; Niehl, A. Nucleic acid-mediated PAMP-triggered immunity in plants. Curr. Opin. Virol. 2020, 42, 32-39. [CrossRef] [PubMed]

10. Motion, G.B.; Amaro, T.M.; Kulagina, N.; Huitema, E. Nuclear processes associated with plant immunity and pathogen susceptibility. Briefings Funct. Genom. 2015, 14, 243-252. [CrossRef]

11. Borrelli, G.M.; Mazzucotelli, E.; Marone, D.; Crosatti, C.; Michelotti, V.; Valè, G.; Mastrangelo, A.M. Regulation and Evolution of NLR Genes: A Close Interconnection for Plant Immunity. Int. J. Mol. Sci. 2018, 19, 1662. [CrossRef] 
12. Lewis, L.A.; Polanski, K.; De Torres-Zabala, M.; Jayaraman, S.; Bowden, L.; Moore, J.; Penfold, C.A.; Jenkins, D.J.; Hill, C.; Baxter, L.; et al. Transcriptional Dynamics Driving MAMP-Triggered Immunity and Pathogen Effector-Mediated Immunosuppression in Arabidopsis Leaves Following Infection with Pseudomonas syringae pv tomato DC3000. Plant Cell 2015, 27, 3038-3064. [CrossRef]

13. Xu, G.; Greene, G.H.; Yoo, H.; Liu, L.; Marqués, J.; Motley, J.; Dong, X. Global translational reprogramming is a fundamental layer of immune regulation in plants. Nature 2017, 545, 487-490. [CrossRef]

14. Naidoo, S.; Visser, E.A.; Zwart, L.; du Toit, Y.; Bhadauria, V.; Shuey, L.S. Dual RNA-Sequencing to Elucidate the Plant-Pathogen Duel. Curr. Issues Mol. Biol. 2018, 27, 127-142. [CrossRef]

15. Moeller, J.R.; Moscou, M.J.; Bancroft, T.; Skadsen, R.W.; Wise, R.P.; Whitham, S.A. Differential accumulation of host mRNAs on polyribosomes during obligate pathogen-plant interactions. Mol. BioSyst. 2012, 8, 2153-2165. [CrossRef]

16. Deng, Y.; Wang, J.; Tung, J.; Liu, D.; Zhou, Y.; He, S.; Du, Y.; Baker, B.; Li, F. A role for small RNA in regulating innate immunity during plant growth. PLoS Pathog. 2018, 14, e1006756. [CrossRef]

17. Islam, W.; Noman, A.; Qasim, M.; Wang, L. Plant Responses to Pathogen Attack: Small RNAs in Focus. Int. J. Mol. Sci. 2018, 19, 515. [CrossRef] [PubMed]

18. De Vries, S.; Rose, L.E. The Elaboration of miRNA Regulation and Gene Regulatory Networks in Plant-Microbe Interactions. Genes 2019, 10, 310. [CrossRef]

19. Zhang, H.; Guo, H.; Hu, W.; Ji, W. The Emerging Role of Long Non-Coding RNAs in Plant Defense Against Fungal Stress. Int. J. Mol. Sci. 2020, 21, 2659. [CrossRef] [PubMed]

20. Rigo, R.; Bazin, J.; Crespi, M.; Charon, C. Alternative Splicing in the Regulation of Plant-Microbe Interactions. Plant Cell Physiol. 2019, 60, 1906-1916. [CrossRef] [PubMed]

21. Nühse, T.S.; Bottrill, A.R.; Jones, A.M.; Peck, S.C. Quantitative phosphoproteomic analysis of plasma membrane proteins reveals regulatory mechanisms of plant innate immune responses. Plant J. 2007, 51, 931-940. [CrossRef]

22. Niu, D.; Lin, X.-L.; Kong, X.; Qu, G.-P.; Cai, B.; Lee, J.; Jin, J.B. SIZ1-Mediated SUMOylation of TPR1 Suppresses Plant Immunity in Arabidopsis. Mol. Plant 2019, 12, 215-228. [CrossRef] [PubMed]

23. Bellin, D.; Asai, S.; Delledonne, M.; Yoshioka, H. Nitric Oxide as a Mediator for Defense Responses. Mol. Plant-Microbe Interact. 2013, 26, 271-277. [CrossRef] [PubMed]

24. Hackmann, C.; Korneli, C.; Kutyniok, M.; Köster, T.; Wiedenlübbert, M.; Müller, C.; Staiger, D. Salicylic acid-dependent and -independent impact of an RNA-binding protein on plant immunity. Plant Cell Environ. 2013, 37, 696-706. [CrossRef]

25. Hewezi, T.; Pantalone, V.; Bennett, M.; Stewart, C.N.; Burch-Smith, T.M. Phytopathogen-induced changes to plant methylomes. Plant Cell Rep. 2017, 37, 17-23. [CrossRef] [PubMed]

26. König, S.; Mosblech, A.; Heilmann, I. Stress-inducible and constitutive phosphoinositide pools have distinctive fatty acid patterns in Arabidopsis thaliana. FASEB J. 2007, 21, 1958-1967. [CrossRef] [PubMed]

27. Gonorazky, G.; Ramirez, L.; Abd-El-Haliem, A.; Vossen, J.H.; LaMattina, L.; Have, A.T.; Joosten, M.H.; Laxalt, A.M. The tomato phosphatidylinositol-phospholipase C2 (SIPLC2) is required for defense gene induction by the fungal elicitor xylanase. J. Plant Physiol. 2014, 171, 959-965. [CrossRef] [PubMed]

28. Li-Beisson, Y.; Shorrosh, B.; Beisson, F.; Andersson, M.X.; Arondel, V.; Bates, P.D.; Baud, S.; Bird, D.; Debono, A.; Durrett, T.P.; et al. Acyl-Lipid Metabolism. In The Arabidopsis Book; Last, R., Ed.; The American Society of Plant Biologists: Rockville, MD, USA, 2013; Volume 8, pp. 1-65.

29. Meijer, H.J.; Munnik, T. Phospholipid-basedsignaling inplants. Annu. Rev. Plant Biol. 2003, 54, 265-306. [CrossRef]

30. Sperling, P.; Heinz, E. Plant sphingolipids: Structural diversity, biosynthesis, first genes and functions. Biochim. Biophys. Acta (BBA) Mol. Cell Biol. Lipids 2003, 1632, 1-15. [CrossRef]

31. Xing, J.; Zhang, L.; Duan, Z.; Lin, J. Coordination of Phospholipid-Based Signaling and Membrane Trafficking in Plant Immunity. Trends Plant Sci. 2021, 26, 407-420. [CrossRef]

32. Okazaki, Y.; Saito, K. Roles of lipids as signaling molecules and mitigators during stress response in plants. Plant J. 2014, 79, 584-596. [CrossRef]

33. Hong, Y.; Zhao, J.; Guo, L.; Kim, S.-C.; Deng, X.; Wang, G.; Zhang, G.; Li, M.; Wang, X. Plant phospholipases D and C and their diverse functions in stress responses. Prog. Lipid Res. 2016, 62, 55-74. [CrossRef] [PubMed]

34. Ramos-Diaz, A.; Brito-Argáez, L.; Munnik, T.; Hérnandez-Sotomayor, S.M.T. Aluminum inhibits phosphatidic acid formation by blocking the phospholipase C pathway. Planta 2006, 225, 393-401. [CrossRef] [PubMed]

35. González-Mendoza, V.M.; Sánchez-Sandoval, M.E.; Munnik, T.; Hernández-Sotomayora, S.T. Biochemical characterization of phospholipases C from Coffea arabica in response to aluminium stress. J. Inorg. Biochem. 2020, 204, 110951. [CrossRef] [PubMed]

36. Sánchez-Sandoval, M.E.; Di-Palma, G.E.R.; González-Mendoza, V.M.; Cab-Guillén, Y.A.; Muñoz-Sanchez, J.A.; Ramos-Díaz, A.; Hernández-Sotomayor, S.M.T. Phospholipid signaling pathway in Capsicum chinense suspension cells as a key response to consortium infection. BMC Plant Biol. 2021, 21, 62. [CrossRef] [PubMed]

37. Wang, X. Lipid signaling. Curr. Opin. Plant Biol. 2004, 7, 329-336. [CrossRef]

38. Balla, T.; Szentpetery, Z.; Kim, Y.J. Phosphoinositide Signaling: New Tools and Insights. Physiology 2009, 24, 231-244. [CrossRef]

39. Mueller-Roeber, B.; Pical, C. Inositol Phospholipid Metabolism in Arabidopsis. Characterized and Putative Isoforms of Inositol Phospholipid Kinase and Phosphoinositide-Specific Phospholipase C. Plant Physiol. 2002, 130, 22-46. [CrossRef] 
40. Hunt, L.; Otterhag, L.; Lee, J.C.; Lasheen, T.; Hunt, J.; Seki, M.; Shinozaki, K.; Sommarin, M.; Gilmour, D.J.; Pical, C.; et al. Gene-specific expression and calcium activation of Arabidopsis thaliana phospholipase C isoforms. New Phytol. 2004, 162, 643-654. [CrossRef]

41. Enrico, M. The French-Italian Public Consortium for Grapevine Genome Characterization The grapevine genome sequence suggests ancestral hexaploidization in major angiosperm phyla. Nature 2007, 449, 463-467. [CrossRef]

42. Verde, I.; Abbott, A.G.; Scalabrin, S.; Jung, S.; Shu, S.; Marroni, F.; Zhebentyayeva, T.; Dettori, M.T.; Grimwood, J.; et al.; The International Peach Genome Initiative. The high-quality draft genome of peach (Prunus persica) identifies unique patterns of genetic diversity, domestication and genome evolution. Nat. Genet. 2013, 45, 487-494. [CrossRef]

43. Ming, R.; Hou, S.; Feng, Y.; Yu, Q.; Dionne-Laporte, A.; Saw, J.H.; Senin, P.; Wang, W.; Ly, B.V.; Lewis, K.L.T.; et al. The draft genome of the transgenic tropical fruit tree papaya (Carica papaya Linnaeus). Nature 2008, 452, 991-996. [CrossRef] [PubMed]

44. Huang, S.; Li, R.; Zhang, Z.; Li, L.; Gu, X.; Fan, W.; Lucas, W.J.; Wang, X.; Xie, B.; Ni, P.; et al. The genome of the cucumber, Cucumis sativus L. Nat. Genet. 2009, 41, 1275-1281. [CrossRef] [PubMed]

45. Wang, W.; Feng, B.; Xiao, J.; Xia, Z.; Zhou, X.; Li, P.; Zhang, W.; Wang, Y.; Møller, B.L.; Zhang, P.; et al. Cassava genome from a wild ancestor to cultivated varieties. Nat. Commun. 2014, 5, 5110. [CrossRef]

46. Denoeud, F.; Carretero-Paulet, L.; Dereeper, A.; Droc, G.; Guyot, R.; Pietrella, M.; Zheng, C.; Alberti, A.; Anthony, F.; Aprea, G.; et al. The coffee genome provides insight into the convergent evolution of caffeine biosynthesis. Science 2014, 345, 1181-1184. [CrossRef]

47. Tuskan, G.A.; DiFazio, S.; Jansson, S.; Bohlmann, J.; Grigoriev, I.; Hellsten, U.; Putnam, N.; Ralph, S.; Rombauts, S.; Salamov, A.; et al. The Genome of Black Cottonwood, Populus trichocarpa (Torr. \& Gray). Science 2006, 313, 1596-1604. [CrossRef]

48. Lang, D.; Ullrich, K.K.; Murat, F.; Fuchs, J.; Jenkins, J.; Haas, F.B.; Piednoel, M.; Gundlach, H.; Van Bel, M.; Meyberg, R.; et al. The Physcomitrella patens chromosome-scale assembly reveals moss genome structure and evolution. Plant J. 2017, 93, 515-533. [CrossRef]

49. The Potato Genome Sequencing Consortium. Genome Sequence and Analysis of the Tuber Crop Potato. Nature 2011, 475, 189-195. [CrossRef]

50. The Tomato Genome Consortium. The tomato genome sequence provides insights into fleshy fruit evolution. Nature 2012, 485, 635-641. [CrossRef]

51. Barchi, L.; Pietrella, M.; Venturini, L.; Minio, A.; Toppino, L.; Acquadro, A.; Andolfo, G.; Aprea, G.; Avanzato, C.; Bassolino, L.; et al. A chromosome-anchored eggplant genome sequence reveals key events in Solanaceae evolution. Sci. Rep. 2019, 9, 1-13. [CrossRef] [PubMed]

52. Kim, S.; Park, M.; Yeom, S.-I.; Kim, Y.-M.; Lee, J.M.; Lee, H.-A.; Seo, E.; Choi, J.; Cheong, K.; Kim, K.-T.; et al. Genome sequence of the hot pepper provides insights into the evolution of pungency in Capsicum species. Nat. Genet. 2014, 46, 270-278. [CrossRef] [PubMed]

53. Bombarely, A.; Rosli, H.G.; Vrebalov, J.; Moffett, P.; Mueller, L.A.; Martin, G.B. A Draft Genome Sequence of Nicotiana benthamiana to Enhance Molecular Plant-Microbe Biology Research. Mol. Plant-Microbe Interact. 2012, 25, 1523-1530. [CrossRef]

54. Edwards, K.D.; Fernandez-Pozo, N.; Drake-Stowe, K.; Humphry, M.; Evans, A.D.; Bombarely, A.; Allen, F.; Hurst, R.; White, B.; Kernodle, S.P.; et al. A reference genome for Nicotiana tabacum enables map-based cloning of homeologous loci implicated in nitrogen utilization efficiency. BMC Genom. 2017, 18, 448. [CrossRef]

55. Bombarely, A.; Moser, M.; Amrad, A.; Bao, M.; Bapaume, L.; Barry, C.S.; Bliek, M.; Boersma, M.R.; Borghi, L.; Bruggmann, R.; et al. Insight into the evolution of the Solanaceae from the parental genomes of Petunia hybrida. Nat. Plants 2016, 2, 16074. [CrossRef] [PubMed]

56. Sasaki, T. International Rice Genome Sequencing Project the map-based sequence of the rice genome. Nature 2005, 436, 793-800. [CrossRef] [PubMed]

57. The International Brachypodium Initiative Genome sequencing and analysis of the model grass Brachypodium distachyon. Nature 2010, 463, 763-768. [CrossRef]

58. Paterson, A.H.; Bowers, J.E.; Bruggmann, R.; Dubchak, I.; Grimwood, J.; Gundlach, H.; Haberer, G.; Hellsten, U.; Mitros, T.; Poliakov, A.; et al. The Sorghum bicolor genome and the diversification of grasses. Nature 2009, 457, 551-556. [CrossRef]

59. Bennetzen, J.L.; Schmutz, J.; Wang, H.; Percifield, R.; Hawkins, J.; Pontaroli, A.C.; Estep, M.; Feng, L.; Vaughn, J.N.; Grimwood, J.; et al. Reference genome sequence of the model plant Setaria. Nat. Biotechnol. 2012, 30, 555-561. [CrossRef]

60. Jiao, Y.; Peluso, P.; Shi, J.; Liang, T.; Stitzer, M.C.; Wang, B.; Campbell, M.S.; Stein, J.C.; Wei, X.; Chin, C.-S.; et al. Improved maize reference genome with single-molecule technologies. Nature 2017, 546, 524-527. [CrossRef]

61. Schmutz, J.; Cannon, S.B.; Schlueter, J.; Ma, J.; Mitros, T.; Nelson, W.; Hyten, D.L.; Song, Q.; Thelen, J.J.; Cheng, J.; et al. Genome sequence of the palaeopolyploid soybean. Nature 2010, 463, 178-183. [CrossRef]

62. Sato, S.; Nakamura, Y.; Kaneko, T.; Asamizu, E.; Kato, T.; Nakao, M.; Sasamoto, S.; Watanabe, A.; Ono, A.; Kawashima, K.; et al. Genome Structure of the Legume, Lotus japonicus. DNA Res. 2008, 15, 227-239. [CrossRef] [PubMed]

63. Tasma, I.M.; Brendel, V.; Whitham, S.A.; Bhattacharyya, M.K. Expression and evolution of the phosphoinositide-specific phospholipase C gene family in Arabidopsis thaliana. Plant Physiol. Biochem. 2008, 46, 627-637. [CrossRef] [PubMed]

64. Drøbak, B.K. The plant phosphoinositide system. Biochem. J. 1992, 288, 697-712. [CrossRef]

65. Yang, J.; Zhang, Y. I-TASSER server: New development for protein structure and function predictions. Nucleic Acids Res. 2015, 43, W174-W181. [CrossRef] 
66. Maruyama, K.; Sakuma, Y.; Kasuga, M.; Ito, Y.; Seki, M.; Goda, H.; Shimada, Y.; Yoshida, S.; Shinozaki, K.; Yamaguchi-Shinozaki, K. Identification of cold-inducible downstream genes of theArabidopsisDREB1A/CBF3 transcriptional factor using two microarray systems. Plant J. 2004, 38, 982-993. [CrossRef]

67. Zhang, Q.; Van Wijk, R.; Zarza, X.; Shahbaz, M.; Van Hooren, M.; Guardia, A.; Scuffi, D.; García-Mata, C.; Ende, W.V.D.; Hoffmann-Benning, S.; et al. Knock-Down of Arabidopsis PLC5 Reduces Primary Root Growth and Secondary Root Formation While Overexpression Improves Drought Tolerance and Causes Stunted Root Hair Growth. Plant Cell Physiol. 2018, 59, $2004-2019$. [CrossRef] [PubMed]

68. Qi, H.; Jiang, Z.; Zhang, K.; Yang, S.; He, F.; Zhang, Z. PlaD: A Transcriptomics Database for Plant Defense Responses to Pathogens, Providing New Insights into Plant Immune System. Genom. Proteom. Bioinform. 2018, 16, 283-293. [CrossRef]

69. Taylor, D.; Sack, J.; Maune, J.; Beckingham, K.; Quiocho, F. Structure of a recombinant calmodulin from Drosophila melanogaster refined at 2.2-A resolution. J. Biol. Chem. 1991, 266, 21375-21380. [CrossRef]

70. Nakamura, Y.; Ngo, A.H. Non-specific phospholipase C (NPC): An emerging class of phospholipase C in plant growth and development. J. Plant Res. 2020, 133, 489-497. [CrossRef]

71. Nakamura, Y.; Awai, K.; Masuda, T.; Yoshioka, Y.; Takamiya, K.-I.; Ohta, H. A Novel Phosphatidylcholine-hydrolyzing Phospholipase C Induced by Phosphate Starvation in Arabidopsis. J. Biol. Chem. 2005, 280, 7469-7476. [CrossRef] [PubMed]

72. Peters, C.; Kim, S.-C.; Devaiah, S.; Li, M.; Wang, X. Non-specific phospholipase C5 and diacylglycerol promote lateral root development under mild salt stress in Arabidopsis. Plant Cell Environ. 2014, 37, 2002-2013. [CrossRef] [PubMed]

73. Ngo, A.H.; Lin, Y.-C.; Liu, Y.-C.; Gutbrod, K.; Peisker, H.; Dörmann, P.; Nakamura, Y. A pair of nonspecific phospholipases C, NPC2 and NPC6, are involved in gametophyte development and glycerolipid metabolism in Arabidopsis. New Phytol. 2018, 219, 163-175. [CrossRef]

74. Peters, C.; Li, M.; Narasimhan, R.; Roth, M.; Welti, R.; Wang, X. Nonspecific Phospholipase C NPC4 Promotes Responses to Abscisic Acid and Tolerance to Hyperosmotic Stress in Arabidopsis. Plant Cell 2010, 22, 2642-2659. [CrossRef] [PubMed]

75. Kocourková, D.; Krčková, Z.; Pejchar, P.; Veselková, Š.; Valentová, O.; Wimalasekera, R.; Scherer, G.F.E.; Martinec, J. The phosphatidylcholine-hydrolysing phospholipase C NPC4 plays a role in response of Arabidopsis roots to salt stress. J. Exp. Bot. 2011, 62, 3753-3763. [CrossRef] [PubMed]

76. Pejchar, P.; Potocky, M.; Novotná, Z.; Veselková, Š.; Kocourková, D.; Valentová, O.; Schwarzerová, K.; Martinec, J. Aluminium ions inhibit the formation of diacylglycerol generated by phosphatidylcholine-hydrolysing phospholipase C in tobacco cells. New Phytol. 2010, 188, 150-160. [CrossRef]

77. Pejchar, P.; Potocký, M.; Krčková, Z.; Brouzdová, J.; Daněk, M.; Martinec, J.; Pejchar, P.; Potocky, M.; Krčková, Z.; Danek, M. Non-specific phospholipase C4 mediates response to aluminum toxicity in Arabidopsis thaliana. Front. Plant Sci. 2015,6 , 66. [CrossRef]

78. Pejchar, P.; Martinec, J. Aluminum ions alter the function of non-specific phospholipase C through the changes in plasma membrane physical properties. Plant Signal. Behav. 2015, 10, e1031938. [CrossRef]

79. Krčková, Z.; Brouzdová, J.; Daněk, M.; Kocourková, D.; Rainteau, D.; Ruelland, E.; Valentová, O.; Pejchar, P.; Martinec, J. Arabidopsis non-specific phospholipase C1: Characterization and its involvement in response to heat stress. Front. Plant Sci. 2015, 6, 928. [CrossRef]

80. Krčková, Z.; Kocourková, D.; Daněk, M.; Brouzdová, J.; Pejchar, P.; Janda, M.; Pokotylo, I.; Ott, P.G.; Valentová, O.; Martinec, J. The Arabidopsis thaliana non-specific phospholipase C2 is involved in the response to Pseudomonas syringae attack. Ann. Bot. 2017, 121, 297-310. [CrossRef]

81. Bargmann, B.O.; Munnik, T. The role of phospholipase D in plant stress responses. Curr. Opin. Plant Biol. 2006, 9, 515-522. [CrossRef]

82. Zheng, L.; Krishnamoorthi, R.; Zolkiewski, M.; Wang, X. Distinct Ca2+ Binding Properties of Novel C2 Domains of Plant Phospholipase D $\alpha$ and $\beta$. J. Biol. Chem. 2000, 275, 19700-19706. [CrossRef]

83. Qin, C.; Wang, X. The Arabidopsis Phospholipase D Family. Characterization of a Calcium-Independent and PhosphatidylcholineSelective PLD $\zeta 1$ with Distinct Regulatory Domains. Plant Physiol. 2002, 128, 1057-1068. [CrossRef] [PubMed]

84. Wilkins, K.E.; Booher, N.J.; Ewang, L.; Bogdanove, A.J. TAL effectors and activation of predicted host targets distinguish Asian from African strains of the rice pathogen Xanthomonas oryzae pv. oryzicola while strict conservation suggests universal importance of five TAL effectors. Front. Plant Sci. 2015, 6, 536. [CrossRef] [PubMed]

85. Magbanua, Z.V.; ArickII, M.; Buza, T.; Hsu, C.-Y.; Showmaker, K.C.; Chouvarine, P.; Deng, P.; Peterson, D.G.; Lu, S. Transcriptomic dissection of the rice-Burkholderia glumae interaction. BMC Genom. 2014, 15, 755. [CrossRef] [PubMed]

86. Wang, Y.; Li, H.; Si, Y.; Zhang, H.; Guo, H.; Miao, X. Microarray analysis of broad-spectrum resistance derived from an indica cultivar Rathu Heenati. Planta 2011, 235, 829-840. [CrossRef]

87. Shankar, A.; Singh, A.; Kanwar, P.; Srivastava, A.K.; Pandey, A.; Suprasanna, P.; Kapoor, S.; Pandey, G.K. Gene Expression Analysis of Rice Seedling under Potassium Deprivation Reveals Major Changes in Metabolism and Signaling Components. PLoS ONE 2013, 8, e70321. [CrossRef] [PubMed]

88. Zhang, T.; Zhao, X.; Wang, W.; Pan, Y.; Huang, L.; Liu, X.; Zong, Y.; Zhu, L.; Yang, D.; Fu, B. Comparative Transcriptome Profiling of Chilling Stress Responsiveness in Two Contrasting Rice Genotypes. PLoS ONE 2012, 7, e43274. [CrossRef] [PubMed]

89. Dubey, S.; Misra, P.; Dwivedi, S.; Chatterjee, S.; Bag, S.K.; Mantri, S.; Asif, M.H.; Rai, A.; Kumar, S.; Shri, M.; et al. Transcriptomic and metabolomic shifts in rice roots in response to $\mathrm{Cr}$ (VI) stress. BMC Genom. 2010, 11, 648. [CrossRef] 
90. Oono, Y.; Yazawa, T.; Kawahara, Y.; Kanamori, H.; Kobayashi, F.; Sasaki, H.; Mori, S.; Wu, J.; Handa, H.; Itoh, T.; et al. GenomeWide Transcriptome Analysis Reveals that Cadmium Stress Signaling Controls the Expression of Genes in Drought Stress Signal Pathways in Rice. PLoS ONE 2014, 9, e96946. [CrossRef]

91. Secco, D.; Jabnoune, M.; Walker, H.; Shou, H.; Wu, P.; Poirier, Y.; Whelan, J. Spatio-Temporal Transcript Profiling of Rice Roots and Shoots in Response to Phosphate Starvation and Recovery. Plant Cell 2013, 25, 4285-4304. [CrossRef]

92. Zhao, W.; Yang, P.; Kang, L.; Cui, F. Different pathogenicities of Rice stripe virus from the insect vector and from viruliferous plants. New Phytol. 2016, 210, 196-207. [CrossRef]

93. Miyata, K.; Kozaki, T.; Kouzai, Y.; Ozawa, K.; Ishii, K.; Asamizu, E.; Okabe, Y.; Umehara, Y.; Miyamoto, A.; Kobae, Y.; et al. The Bifunctional Plant Receptor, OsCERK1, Regulates Both Chitin-Triggered Immunity and Arbuscular Mycorrhizal Symbiosis in Rice. Plant Cell Physiol. 2014, 55, 1864-1872. [CrossRef] [PubMed]

94. Guo, M.; Ruan, W.; Fangliang, H.; Huang, F.; Zeng, M.; Liu, Y.; Yu, Y.; Ding, X.; Wu, Y.; Wu, Z.; et al. Integrative Comparison of the Role of the PHOSPHATE RESPONSE1 Subfamily in Phosphate Signaling and Homeostasis in Rice. Plant Physiol. 2015, 168, 1762-1776. [CrossRef]

95. Makarevitch, I.; Waters, A.J.; West, P.T.; Stitzer, M.; Hirsch, C.N.; Ross-Ibarra, J.; Springer, N.M. Transposable Elements Contribute to Activation of Maize Genes in Response to Abiotic Stress. PLoS Genet. 2015, 11, e1004915. [CrossRef]

96. Campbell, M.T.; Proctor, C.A.; Dou, Y.; Schmitz, A.J.; Phansak, P.; Kruger, G.R.; Zhang, C.; Walia, H. Genetic and Molecular Characterization of Submergence Response Identifies Subtol6 as a Major Submergence Tolerance Locus in Maize. PLoS ONE 2015, 10, e0120385. [CrossRef] [PubMed]

97. Lanver, D.; Müller, A.N.; Happel, P.; Schweizer, G.; Haas, F.B.; Franitza, M.; Pellegrin, C.; Reissmann, S.; Altmüller, J.; Rensing, S.A.; et al. The Biotrophic Development of Ustilago maydis Studied by RNA-Seq Analysis. Plant Cell 2018, 30, 300-323. [CrossRef] [PubMed]

98. Zheng, J.; Fu, J.; Gou, M.; Huai, J.; Liu, Y.; Jian, M.; Huang, Q.; Guo, X.; Dong, Z.; Wang, H.; et al. Genome-wide transcriptome analysis of two maize inbred lines under drought stress. Plant Mol. Biol. 2009, 72, 407-421. [CrossRef] [PubMed]

99. Lanubile, A.; Ferrarini, A.; Maschietto, V.; Delledonne, M.; Marocco, A.; Bellin, D. Functional genomic analysis of constitutive and inducible defense responses to Fusarium verticillioides infection in maize genotypes with contrasting ear rot resistance. $B M C$ Genom. 2014, 15, 710. [CrossRef]

100. Ding, Y.; Murphy, K.M.; Poretsky, E.; Mafu, S.; Yang, B.; Char, S.N.; Christensen, S.A.; Saldivar, E.; Wu, M.; Wang, Q.; et al. Multiple genes recruited from hormone pathways partition maize diterpenoid defences. Nat. Plants 2019, 5, 1043-1056. [CrossRef]

101. Tzin, V.; Fernandez-Pozo, N.; Richter, A.; Schmelz, E.A.; Schoettner, M.; Schäfer, M.; Ahern, K.R.; Meihls, L.N.; Kaur, H.; Huffaker, A.; et al. Dynamic maize responses to aphid feeding are revealed by a time series of transcriptomic and metabolomic assays. Plant Physiol. 2015, 169, 1727-1743. [CrossRef]

102. Zhao, Y.; Hu, F.; Zhang, X.; Wei, Q.; Dong, J.; Bo, C.; Cheng, B.; Ma, Q. Comparative transcriptome analysis reveals important roles of nonadditive genes in maize hybrid An'nong 591 under heat stress. BMC Plant Biol. 2019, 19, 273. [CrossRef]

103. Shin, J.H.; Vaughn, J.N.; Abdel-Haleem, H.; Chavarro, C.; Abernathy, B.; Kim, K.D.; A Jackson, S.; Carolina, C. Transcriptomic changes due to water deficit define a general soybean response and accession-specific pathways for drought avoidance. $B M C$ Plant Biol. 2015, 15, 26. [CrossRef]

104. Belamkar, V.; Weeks, N.T.; Bharti, A.K.; Farmer, A.D.; Graham, M.A.; Cannon, S.B. Comprehensive characterization and RNA-Seq profiling of the HD-Zip transcription factor family in soybean (Glycine max) during dehydration and salt stress. BMC Genom. 2014, 15, 950. [CrossRef] [PubMed]

105. Lambirth, K.C.; Whaley, A.M.; Blakley, I.C.; Schlueter, J.A.; Bost, K.L.; Loraine, A.E.; Piller, K.J. A Comparison of transgenic and wild type soybean seeds: Analysis of transcriptome profiles using RNA-Seq. BMC Biotechnol. 2015, 15, 89. [CrossRef]

106. Letunic, I.; Bork, P. 20 years of the SMART protein domain annotation resource. Nucleic Acids Res. 2018, 46, D493-D496. [CrossRef] [PubMed]

107. Bargmann, B.O.R.; Laxalt, A.M.; Ter Riet, B.; Van Schooten, B.; Merquiol, E.; Testerink, C.; Haring, M.A.; Bartels, D.; Munnik, T. Multiple PLDs Required for High Salinity and Water Deficit Tolerance in Plants. Plant Cell Physiol. 2008, 50, 78-89. [CrossRef]

108. Suzuki, N.; Bassil, E.; Hamilton, J.S.; Inupakutika, M.A.; Zandalinas, S.I.; Tripathy, D.; Luo, Y.; Dion, E.; Fukui, G.; Kumazaki, A.; et al. ABA Is Required for Plant Acclimation to a Combination of Salt and Heat Stress. PLoS ONE 2016, 11, e0147625. [CrossRef] [PubMed]

109. Mane, S.P.; Vasquez-Robinet, C.; Sioson, A.A.; Heath, L.S.; Grene, R. Early PLD $\alpha$-mediated events in response to progressive drought stress in Arabidopsis: A transcriptome analysis. J. Exp. Bot. 2007, 58, 241-252. [CrossRef] [PubMed]

110. Bargmann, B.O.R.; Laxalt, A.M.; Ter Riet, B.; Testerink, C.; Merquiol, E.; Mosblech, A.; Leon-Reyes, A.; Pieterse, C.M.J.; Haring, M.A.; Heilmann, I.; et al. Reassessing the role of phospholipase D in theArabidopsiswounding response. Plant Cell Environ. 2009, 32, 837-850. [CrossRef]

111. Hong, Y.; Zheng, S.; Wang, X. Dual Functions of Phospholipase D $\alpha 1$ in Plant Response to Drought. Mol. Plant 2008, 1, 262-269. [CrossRef] [PubMed]

112. Lu, S.; Bahn, S.C.; Qu, G.; Qin, H.; Hong, Y.; Xu, Q.; Zhou, Y.; Hong, Y.; Wang, X. Increased expression of phospholipase D $\alpha 1$ in guard cells decreases water loss with improved seed production under drought inBrassica napus. Plant Biotechnol. J. 2012, 11, 380-389. [CrossRef] [PubMed] 
113. Bernsdorff, F.; Doering, A.-C.; Gruner, K.; Schuck, S.; Bräutigam, A.; Zeier, J. Pipecolic Acid Orchestrates Plant Systemic Acquired Resistance and Defense Priming via Salicylic Acid-Dependent and -Independent Pathways. Plant Cell 2016, 28, 102-129. [CrossRef] [PubMed]

114. Maekawa, T.; Kracher, B.; Vernaldi, S.; Van Themaat, E.V.L.; Schulze-Lefert, P. Conservation of NLR-triggered immunity across plant lineages. Proc. Natl. Acad. Sci. USA 2012, 109, 20119-20123. [CrossRef] [PubMed]

115. Filichkin, S.A.; Cumbie, J.S.; Dharmawardhana, P.; Jaiswal, P.; Chang, J.H.; Palusa, S.G.; Reddy, A.; Megraw, M.; Mockler, T.C. Environmental Stresses Modulate Abundance and Timing of Alternatively Spliced Circadian Transcripts in Arabidopsis. Mol. Plant 2015, 8, 207-227. [CrossRef]

116. Hong, Y.; Pan, X.; Welti, R.; Wang, X. The effect of phospholipase D $\alpha 3$ in Arabidopsis response to hyperosmotic stress and glucose. Plant Signal. Behav. 2008, 3, 1099-1100. [CrossRef] [PubMed]

117. Gu, Y.; Zebell, S.G.; Liang, Z.; Wang, S.; Kang, B.-H.; Dong, X. Nuclear Pore Permeabilization Is a Convergent Signaling Event in Effector-Triggered Immunity. Cell 2016, 166, 1526-1538. [CrossRef]

118. Dinneny, J.R.; Long, T.A.; Wang, J.Y.; Jung, J.W.; Mace, D.; Pointer, S.; Barron, C.; Brady, S.M.; Schiefelbein, J.; Benfey, P.N. Cell Identity Mediates the Response of Arabidopsis Roots to Abiotic Stress. Science 2008, 320, 942-945. [CrossRef] [PubMed]

119. Siemens, J.; Keller, I.; Sarx, J.; Kunz, S.; Schuller, A.; Nagel, W.; Schmülling, T.; Parniske, M.; Ludwig-Müller, J. Transcriptome Analysis of Arabidopsis Clubroots Indicate a Key Role for Cytokinins in Disease Development. Mol. Plant-Microbe Interact. 2006, 19, 480-494. [CrossRef]

120. Zhao, J.; Wang, C.; Bedair, M.; Welti, R.; Sumner, L.W.; Baxter, I.; Wang, X. Suppression of Phospholipase Dys Confers Increased Aluminum Resistance in Arabidopsis thaliana. PLoS ONE 2011, 6, e28086. [CrossRef]

121. Kopischke, M.; Westphal, L.; Schneeberger, K.; Clark, R.; Ossowski, S.; Wewer, V.; Fuchs, R.; Landtag, J.; Hause, G.; Dörmann, P.; et al. Impaired sterol ester synthesis alters the response of Arabidopsis thalianato Phytophthora infestans. Plant J. 2012, 73, 456-468. [CrossRef] [PubMed]

122. Abdeen, A.; Schnell, J.; Miki, B. Transcriptome analysis reveals absence of unintended effects in drought-tolerant transgenic plants overexpressing the transcription factor ABF3. BMC Genom. 2010, 11, 69. [CrossRef] [PubMed]

123. Yang, L.; Li, B.; Zheng, X.-Y.; Li, J.; Yang, M.; Dong, X.; He, G.; An, C.; Deng, X.W. Salicylic acid biosynthesis is enhanced and contributes to increased biotrophic pathogen resistance in Arabidopsis hybrids. Nat. Commun. 2015, 6, 7309. [CrossRef] [PubMed]

124. Perera, I.Y.; Hung, C.-Y.; Moore, C.D.; Stevenson-Paulik, J.; Boss, W.F. Transgenic Arabidopsis Plants Expressing the Type 1 Inositol 5-Phosphatase Exhibit Increased Drought Tolerance and Altered Abscisic Acid Signaling. Plant Cell 2008, 20, $2876-2893$. [CrossRef]

125. Pandey, N.; Ranjan, A.; Pant, P.; Tripathi, R.K.; Ateek, F.; Pandey, H.P.; Patre, U.V.; Sawant, S.V. CAMTA 1 regulates drought responses in Arabidopsis thaliana. BMC Genom. 2013, 14, 216. [CrossRef]

126. Katagiri, T.; Takahashi, S.; Shinozaki, K. Involvement of a novel Arabidopsis phospholipase D, AtPLD $\delta$, in dehydration-inducible accumulation of phosphatidic acid in stress signalling. Plant J. 2001, 26, 595-605. [CrossRef]

127. Laxalt, A.M.; Munnik, T. Phospholipid signalling in plant defence. Curr. Opin. Plant Biol. 2002, 5, 332-338. [CrossRef]

128. Arisz, S.A.; Testerink, C.; Munnik, T. Plant PA signaling via diacylglycerol kinase. Biochim. Biophys. Acta 2009, 1791, 869-875. [CrossRef]

129. Boss, W.F.; Im, Y.J. Phosphoinositide Signaling. Annu. Rev. Plant Biol. 2012, 63, 409-429. [CrossRef] [PubMed]

130. Nurnberger, T.; Brunner, F.; Kemmerling, B.; Piater, L. Innate immunity in plants and animals: Striking similarities and obvious differences. Immunol. Rev. 2004, 198, 249-266. [CrossRef]

131. De Jong, C.F.; Laxalt, A.M.; Bargmann, B.O.R.; De Wit, P.J.G.M.; Joosten, M.H.A.J.; Munnik, T. Phosphatidic acid accumulation is an early response in theCf-4/Avr4interaction. Plant J. 2004, 39, 1-12. [CrossRef]

132. Song, F.; Goodman, R.M. Molecular cloning and characterization of a rice phosphoinositide-specific phospholipase $C$ gene, OsPI-PLC1, that is activated in systemic acquired resistance. Physiol. Mol. Plant Pathol. 2002, 61, 31-40. [CrossRef]

133. Chen, J.; Zhang, W.; Song, F.; Zheng, Z. Phospholipase C/diacylglycerol kinase-mediated signalling is required for benzothiadiazole-induced oxidative burst and hypersensitive cell death in rice suspension-cultured cells. Protoplasma 2006, 230, 13-21. [CrossRef] [PubMed]

134. Raho, N.; Ramirez, L.; Lanteri, M.L.; Gonorazky, G.; LaMattina, L.; Have, A.T.; Laxalt, A.M. Phosphatidic acid production in chitosan-elicited tomato cells, via both phospholipase D and phospholipase C/diacylglycerol kinase, requires nitric oxide. J. Plant Physiol. 2011, 168, 534-539. [CrossRef]

135. Gonorazky, G.; Guzzo, M.C.; Abd-El-Haliem, A.M.; Joosten, M.H.; Laxalt, A.M. Silencing of the tomato phosphatidylinositolphospholipase C2 (SIPLC2) reduces plant susceptibility to Botrytis cinerea. Mol. Plant Pathol. 2016, 17, 1354-1363. [CrossRef] [PubMed]

136. Vossen, J.H.; Abd-El-Haliem, A.; Fradin, E.F.; Berg, G.C.V.D.; Ekengren, S.K.; Meijer, H.J.; Seifi, A.; Bai, Y.; Have, A.T.; Munnik, T.; et al. Identification of tomato phosphatidylinositol-specific phospholipase-C (PI-PLC) family members and the role of PLC4 and PLC6 in HR and disease resistance. Plant J. 2010, 62, 224-239. [CrossRef]

137. Kiba, A.; Nakano, M.; Hosokawa, M.; Galis, I.; Nakatani, H.; Shinya, T.; Ohnishi, K.; Hikichi, Y. Phosphatidylinositolphospholipase C2 regulates pattern-triggered immunity in Nicotiana benthamiana. J. Exp. Bot. 2020, 71, 5027-5038. [CrossRef] [PubMed] 
138. Kirik, A.; Mudgett, M.B. SOBER1 phospholipase activity suppresses phosphatidic acid accumulation and plant immunity in response to bacterial effector AvrBsT. Proc. Nat. Acad. Sci. USA 2009, 106, 20532-20537. [CrossRef] [PubMed]

139. Johansson, O.N.; Fahlberg, P.; Karimi, E.; Nilsson, A.K.; Ellerström, M.; Andersson, M.X. Redundancy among phospholipase D isoforms in resistance triggered by recognition of the Pseudomonas syringae effector AvrRpm1 in Arabidopsis thaliana. Front. Plant Sci. 2014, 5, 639. [CrossRef] [PubMed]

140. Torres, M.A.; Morales, J.; Sánchez-Rodríguez, C.; Molina, A.; Dangl, J.L. Functional Interplay Between Arabidopsis NADPH Oxidases and Heterotrimeric G Protein. Mol. Plant-Microbe Interact. 2013, 26, 686-694. [CrossRef] [PubMed]

141. Yamaguchi, T.; Kuroda, M.; Yamakawa, H.; Ashizawa, T.; Hirayae, K.; Kurimoto, L.; Shinya, T.; Shibuya, N. Suppression of a Phospholipase D Gene, OsPLD $\beta 1$, Activates Defense Responses and Increases Disease Resistance in Rice. Plant Physiol. 2009, 150, 308-319. [CrossRef]

142. Pinosa, F.; Buhot, N.; Kwaaitaal, M.; Fahlberg, P.; Thordal-Christensen, H.; Ellerström, M.; Andersson, M.X. Arabidopsis

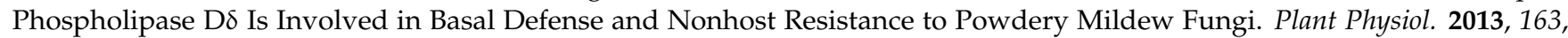
896-906. [CrossRef]

143. Hyodo, K.; Taniguchi, T.; Manabe, Y.; Kaido, M.; Mise, K.; Sugawara, T.; Taniguchi, H.; Okuno, T. Phosphatidic Acid Produced by Phospholipase D Promotes RNA Replication of a Plant RNA Virus. PLoS Pathog. 2015, 11, e1004909. [CrossRef]

144. Li, W.; Li, M.; Zhang, W.; Welti, R.; Wang, X. The plasma membrane-bound phospholipase D $\delta$ enhances freezing tolerance in Arabidopsis thaliana. Nat. Biotechnol. 2004, 22, 427-433. [CrossRef] [PubMed]

145. Zheng, S.-Z.; Liu, Y.-L.; Li, B.; Shang, Z.-L.; Zhou, R.-G.; Sun, D.-Y. Phosphoinositide-specific phospholipase C9 is involved in the thermotolerance of Arabidopsis. Plant J. 2011, 69, 689-700. [CrossRef] [PubMed]

146. Gao, K.; Liu, Y.-L.; Li, B.; Zhou, R.-G.; Sun, D.-Y.; Zheng, S.-Z. Arabidopsis thaliana Phosphoinositide-Specific Phospholipase C Isoform 3 (AtPLC3) and AtPLC9 have an Additive Effect on Thermotolerance. Plant Cell Physiol. 2014, 55, 1873-1883. [CrossRef] [PubMed]

147. Ren, H.; Gao, K.; Liu, Y.; Sun, D.; Zheng, S. The role of AtPLC3 and AtPLC9 in thermotolerance in Arabidopsis. Plant Signal. Behav. 2017, 12, e1162368. [CrossRef]

148. Zhang, Q.; Van Wijk, R.; Shahbaz, M.; Roels, W.; Van Schooten, B.; Vermeer, J.E.M.; Zarza, X.; Guardia, A.; Scuffi, D.; García-Mata C.; et al. Arabidopsis Phospholipase C3 is Involved in Lateral Root Initiation and ABA Responses in Seed Germination and Stomatal Closure. Plant Cell Physiol. 2018, 59, 469-486. [CrossRef] [PubMed]

149. Xia, K.; Wang, B.; Zhang, J.; Li, Y.; Yang, H.; Ren, D. Arabidopsis phosphoinositide-specific phospholipase C 4 negatively regulates seedling salt tolerance. Plant Cell Environ. 2017, 40, 1317-1331. [CrossRef]

150. Li, L.; Wang, F.; Yan, P.; Jing, W.; Zhang, C.; Kudla, J.; Zhang, W. A phosphoinositide-specific phospholipase C pathway elicits stress-induced Ca 2+ signals and confers salt tolerance to rice. New Phytol. 2017, 214, 1172-1187. [CrossRef] [PubMed]

151. Georges, F.; Das, S.; Ray, H.; Bock, C.; Nokhrina, K.; Kolla, V.A.; Keller, W. Over-expression ofBrassica napusphosphatidylinositolphospholipase $\mathrm{C} 2$ in canola induces significant changes in gene expression and phytohormone distribution patterns, enhances drought tolerance and promotes early flowering and maturation. Plant Cell Environ. 2009, 32, 1664-1681. [CrossRef]

152. Wang, C.-R.; Yang, A.-F.; Yue, G.-D.; Gao, Q.; Yin, H.-Y.; Zhang, J.-R. Enhanced expression of phospholipase C 1 (ZmPLC1) improves drought tolerance in transgenic maize. Planta 2008, 227, 1127-1140. [CrossRef] [PubMed]

153. Zhao, M.; Liu, Q.; Zhang, Y.; Yang, N.; Wu, G.; Li, Q.; Wang, W. Alleviation of osmotic stress by H2S is related to regulated PLD $\alpha 1$ and suppressed ROS in Arabidopsis thaliana. J. Plant Res. 2020, 133, 393-407. [CrossRef] [PubMed]

154. Liu, Q.; Zhou, Y.; Li, H.; Liu, R.; Wang, W.; Wu, W.; Yang, N.; Wang, S. Osmotic stress-triggered stomatal closure requires Phospholipase D $\delta$ and hydrogen sulfide in Arabidopsis thaliana. Biochem. Biophys. Res. Commun. 2021, 534, 914-920. [CrossRef] [PubMed]

155. Welti, R.; Li, W.; Li, M.; Sang, Y.; Biesiada, H.; Zhou, H.-E.; Rajashekar, C.B.; Williams, T.D.; Wang, X. Profiling Membrane Lipids in Plant Stress Responses: Role of Phospholipase D $\alpha$ in Freezing-Induced Lipid Changes in Arabidopsis. J. Biol. Chem. 2002, 277, 31994-32002. [CrossRef]

156. Zhang, W.; Qin, C.; Zhao, J.; Wang, X. Phospholipase D 1-derived phosphatidic acid interacts with ABI1 phosphatase 2C and regulates abscisic acid signaling. Proc. Natl. Acad. Sci. USA 2004, 101, 9508-9513. [CrossRef]

157. Hong, Y.; Pan, X.; Welti, R.; Wang, X. Phospholipase D $\alpha 3$ is involved in the hyperosmotic response in Arabidopsis. Plant Cell 2008, 20, 803-816. [CrossRef]

158. Zhang, Y.; Wang, L.; Liu, Y.; Zhang, Q.; Wei, Q.; Zhang, W. Nitric oxide enhances salt tolerance in maize seedlings through increasing activities of proton-pump and $\mathrm{Na}+\mathrm{H}+$ antiport in the tonoplast. Planta 2006, 224, 545-555. [CrossRef]

159. Qian, B.; Li, X.; Liu, X.; Chen, P.; Ren, C.; Dai, C. Enhanced drought tolerance in transgenic rice over-expressing of maize C4 phosphoenolpyruvate carboxylase gene via NO and Ca2+. J. Plant Physiol. 2015, 175, 9-20. [CrossRef]

160. Feng, X.; Liu, W.; Cao, F.; Wang, Y.; Zhang, G.; Chen, Z.-H.; Wu, F. Overexpression of HvAKT1 improves drought tolerance in barley by regulating root ion homeostasis and ROS and NO signaling. J. Exp. Bot. 2020, 71, 6587-6600. [CrossRef] 